\title{
小特集 高周波による核融合プラズマ制御の進展
}

\section{2. 電子サイクロトロン波による 局所加熱・電流駆動を利用した分布制御}

\author{
池田佳隆，久保 伸 ${ }^{1)}$ \\ (日本原子力研究所那珂研究所, ${ }^{1}$ 核融合科学研究所)
}

Plasma Profile Control by Using Local Heating and Current Drive with EC Waves

IKEDA Yoshitaka and KUBO Shin ${ }^{1)}$

Naka Fusion Research Establishment, Japan Atomic Energy Research Institute, Ibaraki 311-0193, Japan

${ }^{1)}$ National Institute for Fusion Science, Toki 509-5292, Japan

(Received 22 November 2004)

\begin{abstract}
Methods of local profile control of electron temperature and current in fusion-oriented devices using electron cyclotron (EC) waves are reviewed. Recent progress in the development of EC heating systems that enable such control is briefly described. The advantageous features of $\mathrm{EC}$ wave heating include local and high power density heating properties. Current drive and electron temperature profile control experiments using EC waves performed in order to improve and investigate plasma confinement properties are also discussed.
\end{abstract}

\section{Keywords:}

Electron Cyclotron Resonance Heating (ECRH), fusion plasma heating, current drive, current

\section{1 はじめに}

電子サイクロトロン $(\mathrm{EC})$ 波は, 工学的な利点として, 真 空中を伝搬できるためアンテナをプラズマから離すこと, および高い電力密度 $\left(1 \mathrm{GW} / \mathrm{m}^{2}\right)$ の伝送が可能であり核融 合炉においてブランケットや遮蔽体の貫通に占める領域が 少なくできることがあげられる，一方，物理的には，基本 的な吸収機構がわかっており理論予想が比較的容易で，局 所的な加熱／電流駆動が可能であり，このため加熱に留ま らずプラズマの不安定制御や熱パルスによる診断ツールと しても期待され，また，すでに実用化されている。これら の利点から国際熱核融合実験炉 (ITER) においても 170 $\mathrm{GHz}, 20 \mathrm{MW}$ の $\mathrm{EC}$ 加熱装置の導入が計画されている $[1]$. さて EC 波によるプラズマ加熱実験は1970年代から開始さ れていたが，1990年代からの $100 \mathrm{GHz}$ 帯の発振源（ジャイ ロトロン)の開発が最近の EC 実験の飛躍に繋がっている. すなわち周波数 $f$ の $\mathrm{EC}$ 波は, 電子サイクロトロン周波数 $f_{\mathrm{ce}}=28.0 \times B(\mathrm{GHz})(B$ : 磁場強度 $(\mathrm{T}))$ に対して $f=f_{\mathrm{ce}}$ (基 本波）または $f=2 f_{\mathrm{ce}}$ (第 2 高調波）を満足する磁場強度の 近傍で局所的に吸収される。比較的吸収の良いモードであ る基本波の $\mathrm{O}$ モードの場合， $f>f_{\mathrm{pe}}$ ，また，第 2 高調波 $\mathrm{X}$ モードの場合には $f>f_{\mathrm{pe}} / \sqrt{2} \quad\left(f_{\mathrm{pe}}=8.98 \sqrt{n_{\mathrm{e}}\left(10^{18} \mathrm{~m}^{-3}\right)}\right.$ $(\mathrm{GHz})$ : 電子プラズマ周波数, $n_{\mathrm{e}}$ : プラズマ電子密度 $)$ を 満たす場合に限り，プラズマ中を伝搬できるので, 100 $\mathrm{GHz}$ 帯の大電力発振管の実現により, プラズマ密度が $10^{20}$ $\mathrm{m}^{-3}$ レベルの大型プラズマ実験装置での EC 実験ができる Author'se-mail: ikeda@naka.jaeri.go.jp, kubo@lhd.nifs.ac.jp
ようになった. 大型プラズマ実験装置では 1$)$ 閉じ込めが 良いため電子温度が高くシングルパス吸収が可能，2） NBI 等のイオン加熱手段を有しておりイオン加熱と電子加 熱の比較が可能, 3 ) 波長が短かく, プラズマの特徵的な長 さ（装置寸法）に比べ電力吸収分布や駆動電流分布を十分 に狭くでき，さらに，それらの分布計測が可能である等， 従来の小型実験装置と比べ大幅に実験領域 /計測条件が拡 充されている. またターゲットとなるプラズマ自体も，こ の数年で, 内部輸送障壁 (ITB) や高ベータ化を妨げる新古 典テアリングモード (NTM) の発見およびこれらの制御手 法の開発が進み, ECによる局所的な電子加熱や電流駆動 の手段としての効果に関心が高まっている. 本稿では, 100 $\mathrm{GHz}$ 帯, MW級のジャイロトロン等のハードウエアの開発 状況およびそれによる EC 加熱装置の進展を簡単に述べた 後, トーラス装置におけるプラズマの分布制御, 閉じ达め 改善に向けて進められている EC 電流駆動 (ECCD), NTM 抑制, ITB制御などECを用いた実験を中心に紹介する.ま た熱輸送の計測手法についても簡単に紹介する．最後に高 ベー夕実験装置である球状トーラスや逆転磁場ピンチ, ま た, 高電子密度プラズマの電子加熱方法として最近盛んに 研究が進められている電子バーンシュタイン加熱の動向に ついて簡単に記す。なお, EC 実験に関しては, 多くのレ ビューがあり,より詳細に知りたい方は, 参考文献 $[2-5]$ 等 をお勧めする. 


\section{2 加熱装置の進展}

EC 実験に当っては，前章で述べたように大電力発振管 であるジャイロトロンの開発が鍵である．特に高い周波数 での長パルス運転を行うためには，ジャイロトロンの主要 コンポーネントの熱負荷を低減する必要がある。これに対 して日本では日本原子力研究所が東芝と協力して，コレク ターの熱負荷を低減する電子ビームエネルギー回収 $(\mathrm{CPD})$, 発振モードから高効率で伝送モードに変換する モード変換器の内蔵，低損失のダイヤモンド空装着等，現 在の $100 \mathrm{GHz}$ 帯ジャイロトロンの基本的な機能を世界に先 駆けて開発してきた $[6]$ 。これらの1990年代前半から後半 にかけての技術的ブレークスルーを経て現在，ITER 用と して $170 \mathrm{GHz} ， 1 \mathrm{MW}$ ，連続運転用ジャイロトロンの開発 が，ロシア，米国，欧州，そして日本で進められている。 Fig. 1 に，100 GHz 帯ジャイロトロン開発の進展を示す.

ジャイロトロンで発振した大電力高周波は，アンテナま で低損失で伝送する必要がある。この大電力伝送方式とし ては，導波管伝送方式と，ガウスビームとして空間伝送さ せるビーム伝送方式との 2 種類が考えられる $[7]$. 前者は, 円形導波管の内面に $1 / 4$ 波長程度の溝加工を施すことで, 導波管壁面に電流がほとんど流れない $\mathrm{HE}_{11}$ モードを主要 伝送モードとするもので，低損失で，高い電力伝送密度を 得ることが可能である。一方，ビーム伝送方式は，凹面鏡 列によりビームを集束させながら長距離伝送するものであ り，構造が比較的簡単で，不要モードの影響を受けにくい 等の利点を有しているが，空間的にビームが拡がるため大 きな鏡が必要であるとともに，光軸調整を高い精度で行う 必要が生じる。このため，どちらの方式を採用するかは， 装置の環境条件によって決められている. アンテナに関し ては，真空容器内の最終段の鏡を可動鏡とすることで入射 角度を変え，局所的な加熱／電流駆動の位置を制御するの

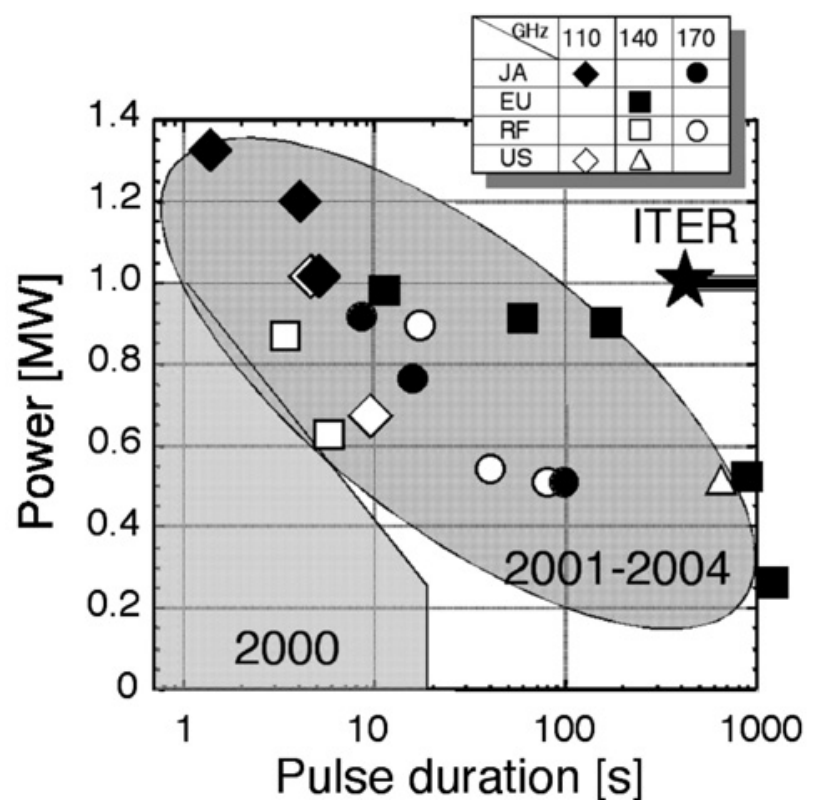

Fig. 1 Progresses of high power gyrotrons at the frequency of $110-170 \mathrm{GHz}$ in Japan (JA), Europe (EU), Russia (RF) and US.
が一般的である. トカマク装置ではディスラプション時の 電磁力等を考慮した構造設計が必要であるが, 既にプラズ マ中に入射位置をフィードバック制御するアンテナが JT60Uで開発されその有効性が検証されている．なお核融合 炉では放射線や熱負荷の観点から可動鏡等の可動部分をプ ラズマから離すことが望ましいが，この課題に対して，導 波管の手前に可動鏡を設置するリモートステアリングアン テナの開発が進められ[8-11], 最近, TRIAM-1M で実用に 供された[11]. Table 1 に, $100 \mathrm{GHz}$ 帯の EC 加熱装置の状 況を示す(表中，斜体文字は現在建設中).なおジャイロト ロンの発振パワー, パルス幅は目標值のものが多く, 現在, 各装置とも目標に向けて開発が進められている.

\section{3 プラズマの分布制御, 閉じ込め改善への寄与}

$\mathrm{EC}$ 波を用いた実験は，発振管の大幅な進展により，現在 世界の多くの核融合装置で精力的に進められている．従来 は比較的小型装置において，オーミックプラズマをター ゲットとした電子加熱や MHD 振動の抑制が研究の中心で あったが，最近は中，大型プラズマ実験装置の実験開始に より, NBI加熱プラズマをターゲットとして，局所的な EC 電流駆動 $(\mathrm{ECCD})$ によるプラズマ性能の向上を主眼におい て実験が進められている．また EC 加熱装置の性能の進展 と併せてモーショナルシュタルク計測（MSE）による局所 的な電流分布測定方法の開発も ECによる分布制御研究を 大きく進展させている

\subsection{1 局所電流駆動}

電流駆動実験に関しては，既に1980年代中頃に WT-2卜 カマクで低電流（3kA）であるものの完全電流駆動を実証 [27］していたが，近年行われた TCV の MW 級の入射実験 では200 kAを超える非誘導プラズマ電流の保持，さらには リチャージングに成功している $[28]$ 。 またW7-AS では EC の入射方向を変え，プラズマ電流の生成量の差から， EC の駆動電流量およびブートストラップ電流量の評価を行っ ている[23]。これらの実験に対して，ECCD の特長である 局所電流駆動の検証(電流分布測定)については，モーショ ナルシュタルク（MSE）計測法の開発により初めて実現さ れた。この手法は 1 ) NBI のビーム発光のモーショナル シュタルク効果により内部のポロイダル磁場を求め, その 結果より全体の電流分布を求める，2）MSE のデー夕を基 にプラズマ平衡解を求め, そのポロイダル磁束の時間微分 よりトロイダル電場を求めて誘導電流分布を算出， 3 ) 全 体の電流から誘導電流分を引くことで非誘導電流方式 （EC）による駆動電流分布を求めるものである [29]．DIIID と JT-60U で，本手法により ECCD の実験と理論との比 較が行われた。 DIII-D では電子系のベー夕值を変えた場合 の駆動位置に対する電流駆動特性を研究し, ベー夕值の上 昇とともに，周辺部で局所的なミラー磁場に補足される電 子が少なくなり駆動電流の減少が抑えられることを明らか にした $[30]$ 。これはべータ值が高い，すなわち電子温度が 高い場合，共鳴条件： $\omega-k_{\|} v_{\|}-m \omega_{\mathrm{ce}} / \gamma$ (ここで， $\omega$ は入射 する $\mathrm{EC}$ 波の角周波数， $k_{\|}$は磁場方向の波数， $v_{\|}$は磁場方 向の電子速度, $\omega_{\mathrm{ce}}$ は電子サイクロトロン角周波数, $m$ は高 
Table 1 EC Heating System in $100 \mathrm{GHz}$ range.

\begin{tabular}{|c|c|c|c|c|c|c|c|}
\hline $\begin{array}{c}\text { Device } \\
\text { [reference] }\end{array}$ & $\begin{array}{l}\text { Frequency } \\
\qquad(\mathrm{GHz})\end{array}$ & Mode & $\begin{array}{l}\text { Power } \\
\quad \times \\
\text { Number }\end{array}$ & $\begin{array}{l}\text { Pulse } \\
\text { width } \\
\text { (s) }\end{array}$ & $\begin{array}{l}\text { Trans- } \\
\text { mission } \\
\text { shcheme }\end{array}$ & $\begin{array}{c}\text { Injected } \\
\text { Power } \\
(\mathrm{MW})\end{array}$ & Specific Features \\
\hline $\begin{array}{l}\text { JT-60 } \\
{[12]}\end{array}$ & 110 & 1st, $\mathrm{O}$ & $1 \mathrm{MW} \times 4$ & $5 \mathrm{~s}$ & $\mathrm{~W} / \mathrm{G}$ & 3 & $\begin{array}{l}\text { Hybrid heating with NB, RF } \\
\text { ECCD with MSE current measurement } \\
\text { Real time feedback of heating position }\end{array}$ \\
\hline $\begin{array}{l}\text { DIII-D } \\
{[13]}\end{array}$ & 110 & 2nd, $X$ & $1 \mathrm{MW} \times 6$ & $10 \mathrm{~s}$ & $\mathrm{~W} / \mathrm{G}$ & 3.5 & $\begin{array}{l}\text { Hybrid heating with NB, RF } \\
\text { ECCD with MSE current measurement }\end{array}$ \\
\hline $\begin{array}{l}\text { RTP } \\
{[14]}\end{array}$ & $\begin{array}{c}60 \\
110\end{array}$ & $\begin{array}{l}\text { 1st, O } \\
\text { 2nd, X }\end{array}$ & $\begin{array}{l}0.2 \mathrm{MW} \times 2 \\
0.5 \mathrm{MW} \times 1\end{array}$ & $\begin{array}{l}0.1 \mathrm{~s} \\
0.2 \mathrm{~s}\end{array}$ & Beam & $\begin{array}{l}0.15 \\
0.35\end{array}$ & $\begin{array}{l}\text { Fundamental+ } \\
\text { Second Harmonic } \\
\text { (Shutdown) }\end{array}$ \\
\hline $\begin{array}{l}\text { TCV } \\
{[15,16]}\end{array}$ & $\begin{array}{l}82.7 \\
118 \\
\end{array}$ & $\begin{array}{l}\text { 2nd, } X \\
\text { 3rd, X }\end{array}$ & $\begin{array}{l}0.5 \mathrm{MW} \times 6 \\
0.5 \mathrm{MW} \times 3\end{array}$ & $\begin{array}{l}2 \mathrm{~s} \\
2 \mathrm{~s}\end{array}$ & $\mathrm{~W} / \mathrm{G}$ & $\begin{array}{c}2.8 \\
1.35 \\
\end{array}$ & $\begin{array}{l}\text { Second }+ \\
\text { Third Harmonic }\end{array}$ \\
\hline $\begin{array}{l}\text { Tore-Supra } \\
{[17]}\end{array}$ & 118 & 1st, $\mathrm{O}$ & $\begin{array}{l}0.4 \mathrm{MW} \times 2 \\
0.4 M W \times 6\end{array}$ & $\begin{array}{r}50 \mathrm{~s} \\
600 \mathrm{~s} \\
\end{array}$ & $\mathrm{~W} / \mathrm{G}$ & 0.7 & $\begin{array}{l}\text { Hybrid heating with RF } \\
\text { Long pulse injection }\end{array}$ \\
\hline $\begin{array}{l}\text { ASDEX-U } \\
{[18]}\end{array}$ & $\begin{array}{c}140 \\
105 / 140 \\
\end{array}$ & 2nd, $X$ & $\begin{array}{c}0.5 \mathrm{MW} \times 4 \\
1 M W \times 4\end{array}$ & $\begin{array}{c}10 \mathrm{~s} \\
2 s\end{array}$ & $\begin{array}{c}\text { Beam+ } \\
W / G\end{array}$ & 1.6 & Hybrid heating with NB \\
\hline $\begin{array}{l}\text { FTU } \\
{[19]}\end{array}$ & 140 & 1 st, $\mathrm{O}$ & $0.4 \mathrm{MW} \times 4$ & $0.5 \mathrm{~s}$ & $\mathrm{~W} / \mathrm{G}$ & 0.7 & Hybrid heating with RF \\
\hline $\begin{array}{l}\text { T-10 } \\
{[20,21]}\end{array}$ & $\begin{array}{l}130 \\
140\end{array}$ & $\begin{array}{l}\text { 2nd, X } \\
\text { 2nd, X }\end{array}$ & $0.25 \mathrm{MW} \times 4$ & - & - & 0.9 & Two frequency heating \\
\hline $\begin{array}{l}\text { TEXTOR } \\
\text { [22] }\end{array}$ & $\begin{array}{l}110 \\
140\end{array}$ & $\begin{array}{l}\text { 2nd, X } \\
\text { 2nd, X }\end{array}$ & $\begin{array}{l}0.5 \mathrm{MW} \times 1 \\
0.8 \mathrm{MW} \times 1\end{array}$ & $\begin{array}{c}0.2 \mathrm{~s} \\
3 \mathrm{~s}\end{array}$ & $\mathrm{~W} / \mathrm{G}$ & $\begin{array}{l}0.3 \\
0.8\end{array}$ & Hybrid heating with NB, RF \\
\hline $\begin{array}{l}\text { W7-AS } \\
{[23]}\end{array}$ & $\begin{array}{c}70 \\
140\end{array}$ & $\begin{array}{l}\text { 1st, O } \\
\text { 2nd, X }\end{array}$ & $\begin{array}{l}0.5 \mathrm{MW} \times 1 \\
0.8 \mathrm{MW} \times 4\end{array}$ & $\begin{array}{c}- \\
0.5 \mathrm{~s}\end{array}$ & $\begin{array}{c}\text { Beam }+ \\
\text { W/G }\end{array}$ & $\begin{array}{l}0.5 \\
2.3\end{array}$ & $\begin{array}{l}\text { High Density heating, } \\
\text { Bernstein heating, ECCD } \\
\text { (Shutdown) }\end{array}$ \\
\hline $\begin{array}{l}W 7-X \\
{[24]} \\
\end{array}$ & 140 & $2 n d, X$ & $1 \mathrm{MW} \times 10$ & $C W$ & Beam & & CW operation \\
\hline $\begin{array}{l}\text { LHD } \\
{[25]}\end{array}$ & $\begin{array}{c}82.7 \\
84 \\
168 \\
\end{array}$ & $\begin{array}{l}1 \text { st, O } \\
1 \text { st, O } \\
\text { 2nd, X }\end{array}$ & $\begin{array}{l}0.5 \mathrm{MW} \times 2 \\
0.8 \mathrm{MW} \times 2 \\
0.5 \mathrm{MW} \times 4\end{array}$ & $\begin{array}{l}2 \mathrm{~s} \\
3 \mathrm{~s} \\
1 \mathrm{~s}\end{array}$ & $\mathrm{~W} / \mathrm{G}$ & $\begin{array}{l}0.5 \\
0.8 \\
0.7\end{array}$ & $\begin{array}{l}\text { Hybrid heating with NB, RF } \\
\text { Fundamental+ } \\
\text { Second hramonic }\end{array}$ \\
\hline $\begin{array}{l}\text { TRIAM-1M } \\
\text { [26] }\end{array}$ & 170 & 1 st, O & $0.2 \mathrm{MW} \times 1$ & $5 \mathrm{~s}$ & $\mathrm{~W} / \mathrm{G}$ & 0.15 & $\begin{array}{l}\text { Hybrid heating with,LH } \\
\text { Remote Steering Antenna }\end{array}$ \\
\hline
\end{tabular}

調波次数, $\gamma$ は相対論指数) を満たす電子の $v_{\|} / v_{\perp}$ が大きく なり，補足電子の影響が減るためであると考えられる。一 方，JT-60Uでは，低域混成波と併せて $21 \mathrm{keV}$ という炬心 レベルの高電子プラズマにおける駆動電流特性を調べ，高 加熱密度における誘導電場の効果を入れた理論計算で実験 結果をよく説明できることを明らかにした $[31]$ 。これらの 結果から, ITER 等の高温, 高密度プラズマでの EC 電流駆 動は，ほぼ現在の理論で予想できると考えられる. Fig. 2 に，世界の装置における電子温度に対する電流駆動効率を 示す.

\subsubsection{NTM 抑制}

局所電流駆動によるプラズマ不安定の抑制に関しては, 従来，鋸歯状振動や MHD 振動の抑制等で実験が行われて きたが，最近のトピックスとしては，新古典ティアリング モード（NTM）抑制がある．NTM不安定性は磁気島の発 生による圧力勾配の減少によりブートストラップ電流が減 少するために起るものであり，このためプラズマの高圧力 化を妨げる要因となっている。 これに対し，ECで磁気島中 に局所的に電流駆動を行い，磁気島中の減少したブートス トラップ電流を代替し，NTM 不安定性を抑制することが 提案されていた $[34]$.この ECCD の NTM 不安定性に対す

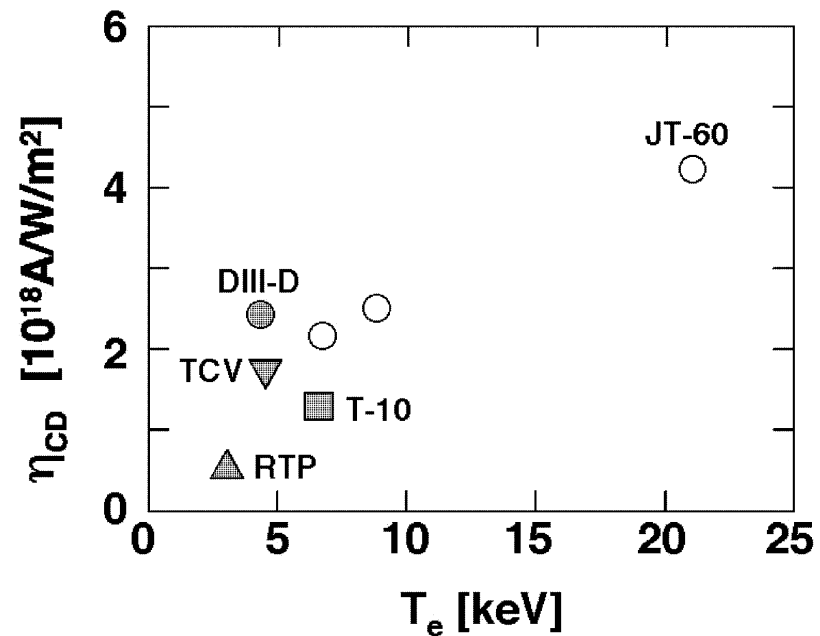

Fig. 2 Current drive efficiency as a function of electron temperature on various devices: JT-60[31], DIII-D[30], TCV[28], RTP[32], T-10[33].

る抑制効果は, ASDEX-U において ECCD 中に $3 / 2$ モード が減少することで初めて確認された [35]. その後, JT-60 U, DIII-D さらに ASDEX-Uで, ECCD の入射位置を最適 化することで $3 / 2$ モードを完全に抑制しベータ值が回復す 
ることが確認された[36-38]．さらにJT-60U では，Fig. 3 に示すようにショット中に磁気島位置を検出し，その位置 に可動鏡でECCDを行うフィードバック制御を行うことに 成功し [39]，ITER で想定される ECCD シナリオを実証し た。また，NTMの成長率が磁気島の幅に依存しているこ とから，磁気島が小さい時点で ECCD を入射すること で, 少ない ECCD でNTM が抑制できることも最近確認さ れた [40].これらの実験結果により，NTM の理論モデル の検証が進むとともに, ITERでのECの役割がより明確に なってきた。

\subsection{3 径電場形成と ITB・電子ルート}

磁場閉じ込め装置においては新古典論で予測される低衝 突領域に打ける閉じ込めの変化，および電場の形成による 閉じ込めの改善が重要なテーマである. EC 波はこの現象 を実験的に確かめるために最適な加熱法である。つまり， $\mathrm{EC}$ 波の加熱機構は電子の磁場に垂直方向のエネルギーを 増大させるため，電子を新古典拡散理論で予測される速度 空間上のロスコーンに追い込むことで，電子の空間的な局 所粒子束を増加させ，準中性条件から決定される電位を正 に引き上げる．この結果，能動的に径方向電場を形成する ことが可能となる。特に，ヘリカル型プラズマ閉じ込め装 置においては，低衝突領域で予測される閉じ込めの劣化と 電場によるその緩和，さらには，電子ルートと呼ばれる閉 じ込めの良い状態が予想されている。このためへリカル装 置では径電場に関する研究が精力的に進められ，実際， CHS において局所的な EC 加熱による径電場の形成が確認 された 441$]$ ささらにW7-AS においては EC 加熱により，中 心部に拡散係数の低い領域を作ることに成功し，電子ルー トが実現したと主張している [42].CHS や LHDにおいて は ECによる径電場のシアが異常拡散の局所的な抑制を引 き起こし，これがITB形成の主要因となったと考えられて

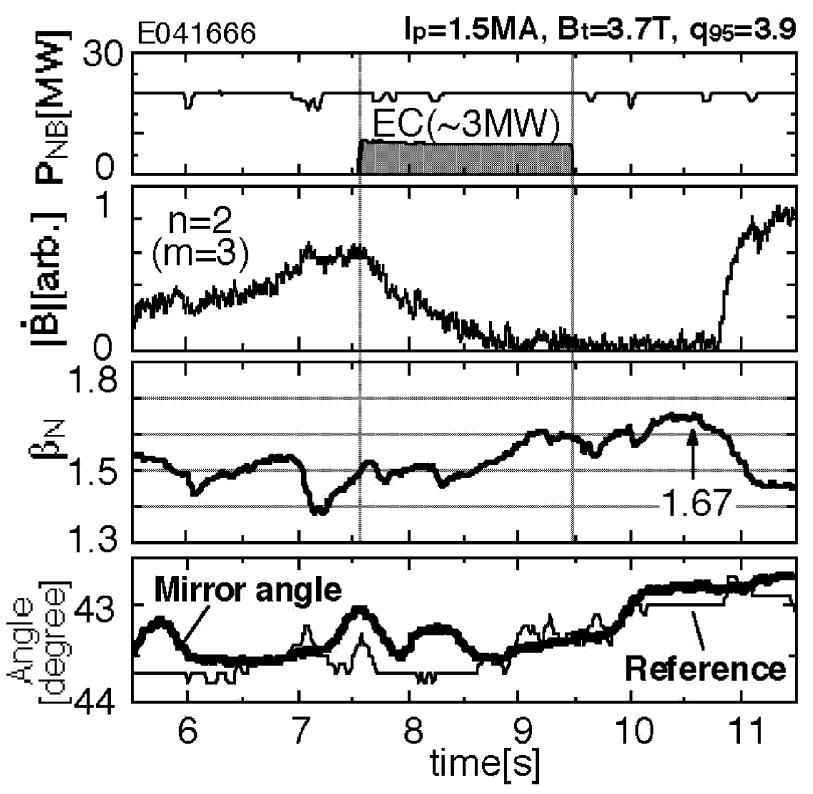

Fig. 3 Typical waveforms of NTM suppression experiment. From the top, NB power and EC power, amplitude of magnetic fluctuation, $\beta_{\mathrm{N}}$, angle of $\mathrm{EC}$ mirror and its reference value.
いる. Fig. 4 にLHD における電子系ITB 形成時の電子温度 分布とその生成条件を示す [43]. 最近CHSではITB形成時 にこの径電場のシア（構造形成）を直接重イオンビームプ ローブ(HIBP)で観測して話題になっている [44]. 一方, 小 型トカマクの EC 実験でも，電子系 ITB に関する研究が進 められ，RTP では，安全係数 $(q)$ 分布の有理面で電子系の ITBが見られること $[45]$,さらにT-10トカマクでは ECCD により電流分布を平坦化した場合, 電子系の ITBが形成さ れることを明らかにした[46]．T-10の場合，電流分布計測 は行われていないがポテンシャル分布の測定により加熱位 置近傍で局所的なポテンシャル井戸が観測された。一方， JT-60Uでは, LH のみで生成した電子系の ITB を有する負 磁気シアプラズマの ITB 内部を EC 加熱することで, 電子 系 ITB を維持したまま電子温度を $26 \mathrm{keV}$ (電子サイクロト ロン放射（ECE）計測值）まで上げることに成功している [47]. この場合， $q_{\min }$ 近傍で電流分布の変化を伴う電子温 度のマイナーコラプスが鋸歯状に振動する現象が観測され ており [48], 今後の負磁気シアの安定性研究が待たれる.

イオン系のITB としては, NBI 加熱時に発見された高ポ ロイダルベータ $\left(\beta_{\mathrm{p}}\right)$ モード [48] と負磁気シアでの ITB [49] がよく知られているが，これまで強力な電子加熱手段がな かったため, 実験領域は $T_{\mathrm{i}}>T_{\mathrm{e}}$ に限られていた. アルファ 粒子による電子加熱が主となる核融合炉では $T_{\mathrm{i}} \sim T_{\mathrm{e}}$ とな るため, 中, 大型プラズマ実験装置で始まったEC加熱実験 においては, NBI加熱により生成したイオン系ITBに対す る電子加熱の影響を調べることが重要な課題となってい る.いち早く EC 加熱実験を初めた ASDEX-U では, NBI 加熱で生成されたイオン系のITBを持つ負磁気シアプラズ マをターゲットとし, 中心部に Counter-ECCD（プラズマ 電流と反対方向の EC 電流駆動) と Co-ECCD（プラズマ電 流と同じ方向の EC 電流駆動）との比較を行った。この結

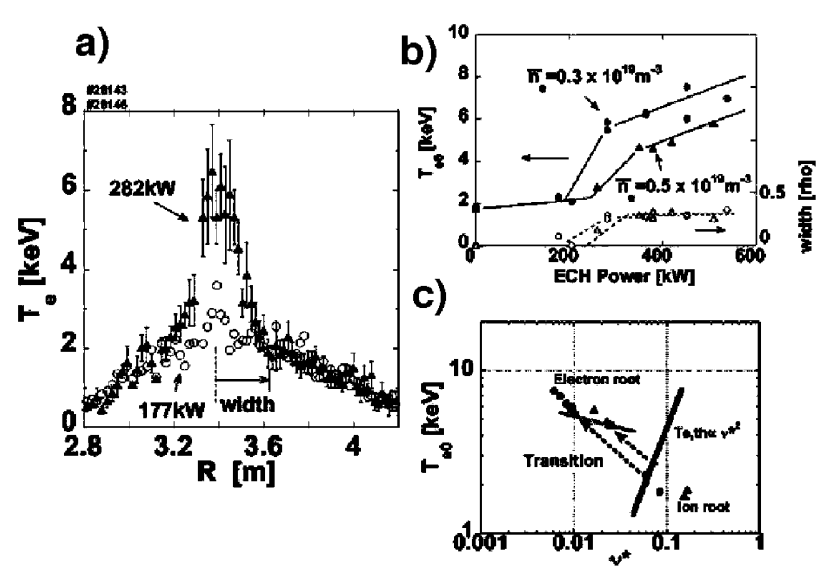

Fig. 4 (a) Te profile with (282 kW injection $\mathbf{\Delta}$ ) and without (177 kW injection $\bigcirc$ ) ITB. (b) Averaged central electron temperature as a function of injected $\mathrm{ECH}$ power for two line-averaged electron densities of $0.3 \times 10^{19}$ and $0.5 \times 10^{19} \mathrm{~m}^{-3}$. The 'width' defined as indicated in (a) is also plotted in terms of the normalized minor radius $\rho$. (c) $T_{\mathrm{e} 0}$ is plotted as a function of electron collisionality. The thick line calculated from the ambipolarity condition divides the area into two (electron and ion root). 
果，Counter-ECCD の場合，イオン系と電子系の両方に明 瞭な ITB を示し $T_{\mathrm{i}} \sim T_{\mathrm{e}} \sim 13 \mathrm{keV}$ のプラズマを得たが, Co -ECCD では，イオン温度が減少し，ITBが弱まることを明 らかにした[50].また, DIII-Dでは周辺部にCo-ECCDを行 うことで負磁気シアを維持し，イオン系，電子系ともに ITBが持続できることを示した[51]. これに対してJT-60U では, NBI加熱で生成した強い負磁気シアと高 $\beta_{\mathrm{p}}$ での異な る ITB について EC 加熱の影響を調べた。この結果，強い 負磁気シアではイオン系の輸送の劣化がなく電子系におい ても明暸な ITB を形成できるが，高 $\beta_{\mathrm{p}}$ では，EC加熱によ りイオン系の輸送が劣化するとともに, 高 $\beta_{\mathrm{p}}$ のITBの特長 である径電場シアが減少していることが明らかになった [52]．さらに興味深い結果としては，強い負磁気シアの場 合には，EC加熱を行っても電子密度㧍よび不純物の減少 は観測されないが, 高 $\beta_{\mathrm{p}}$ では電子密度抢よび不純物が減少 することが明らかになった[53]. Fig. 5 に負磁気シアと高 $\beta_{\mathrm{p}}$ での EC 加熱前後のプラズマの変化を示す. 負磁気シア が弱い場合 ASDEX-UやDIII-Dでも重金属等の不純物排出 が観測されている。これまでの小型トカマクやステラレー 夕での EC 単独加熱実験でも，プラズマ密度の減少は一般 的に観測されており，高 $\beta_{\mathrm{p}}$ でも，この $\mathrm{EC}$ 加熱の特長が保 持されている。一方, 強い負磁気シアでは密度減少が見ら れない（図中，強い負磁気シアでの $\mathrm{Ar}$ 量の増加は， $\mathrm{EC}$ 入射によるものではなく, 時間的な蓄積によるもの)。この ように EC 加熱により 2 つの ITB の挙動は大きく異なって おり, そのメカニズムの解明は今後の研究課題として残さ れている.

\subsection{4 熱輸送の計測}

$\mathrm{EC} は$, 局所的な電子加熱或いは電流駆動という特長か ら，プラズマの電子系の熱輸送解析の手段としても注目を 集めるようになってきた，従来，電子系の熱輸送解析は鋸 歯状振動の過渡応答解析を行っていたが, 大電力の EC 実 験により，その入射電力を高速変調することで計測の精度 を高めることが可能である．EC の吸収分布をデル夕関数 とした簡単なスラブ近似では，ECの変調角周波数を $\omega_{\mathrm{m}}$, 密度で規格化した多調電力を $P_{0}$, 熱輸送係数を $x$ とす ると変調成分の熱平衡輸送方程式は以下の式で与えられる [54].

$$
\frac{3}{2} \frac{\partial \tilde{T}}{\partial t}=\chi \nabla^{2} \tilde{T}+P_{0} \delta(x) \mathrm{e}^{i \omega_{\mathrm{m}} t}
$$

加熱領域外への熱波動の伝播解は

$$
\tilde{T}=A(x) \mathrm{e}^{-i \phi(x)+i \omega_{\mathrm{m}} t}=\frac{P_{0}}{\left(6 \chi \omega_{\mathrm{m}}\right)^{1 / 2}} \mathrm{e}^{-k|x|+i\left(\omega_{\mathrm{m}} t-\pi / 4\right)}
$$

で与えられこの解より $x$ は以下で求められる.

$$
\chi=\frac{3 \omega_{\mathrm{m}}}{4} /\left(\frac{\mathrm{d} \phi(x)}{\mathrm{d} x}\right)^{2}=-\frac{3 \omega_{\mathrm{m}}}{4} /\left(\frac{\mathrm{d} \ln A(x)}{\mathrm{d} x}\right)^{2}
$$

ここで, $k=\left(3 i \omega_{\mathrm{m}} / 2 \chi\right)^{1 / 2}$ であり, $A, \phi$ は計測位置における 電子温度の振幅扮よび入射波との位相差である. 最近で は，EC の吸収分布をガウス分布で与えた輸送方程式を解
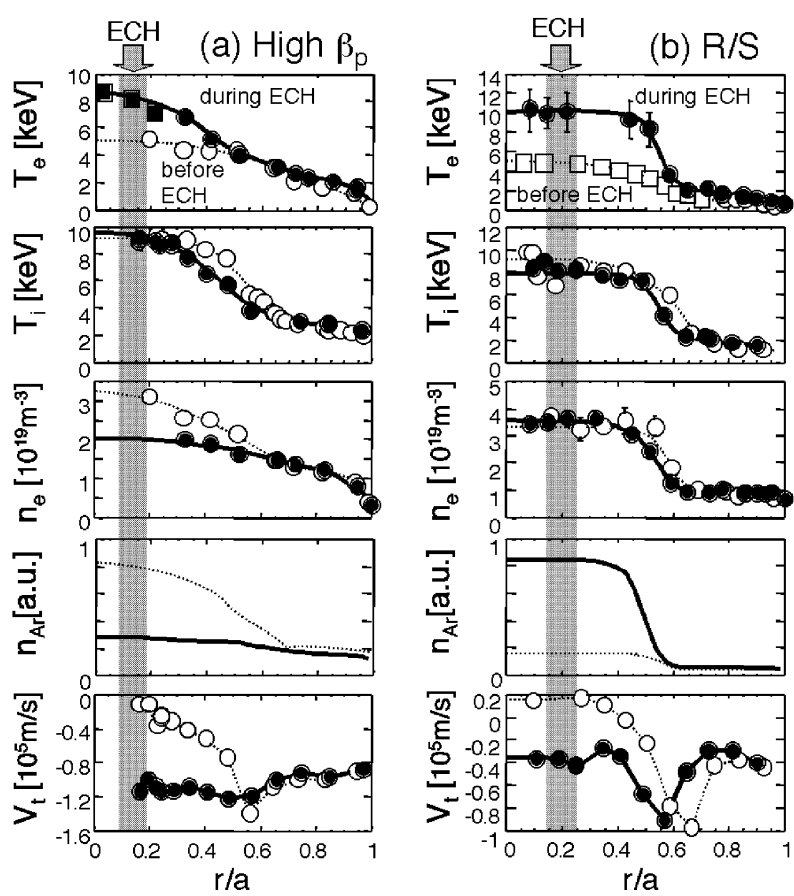

Fig. 5 Profiles of $T_{\mathrm{e}}, T_{\mathrm{i}}, n_{\mathrm{e}}, n_{\mathrm{Ar}}$ and toroidal rotation before $(\bigcirc,---)$ and during $(\mathbf{O},-) \mathrm{EC}$ in the (a) high $\beta_{\mathrm{p}}$ mode plasma and (b) reversed shear $(\mathrm{R} / \mathrm{S})$ plasma. The deposition positions of $E C$ waves are around $r / a=0.15$ and 0.2 , respectively.

いて，熱輸送係数を求めるだけでなく，吸収分布まで実験

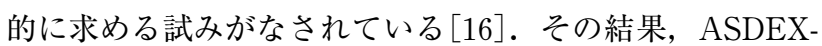
Uでは, ECの加熱位置の内側では熱輸送係数の劣化は観測 されないが，外側では熱輸送係数の大幅な劣化を示す結果 を得た。これは前章で記述したITB を有さないプラズマで は，電子温度勾配が加熱パワーによらず一定であるという 温度分布の硬直性と呼ばれる現象とリンクしており, 電子 温度勾配不安定性（ETG）モード等の熱拡散係数の電子温 度, 電子温度勾配に対する依存性など詳細な輸送研究の ッールとして ECによる熱輸送計測が定着しつつある [5557].

\section{4 新しい加熱研究の動向}

閉じ込め磁場の圧力に対するプラズマの圧力の割合 (ベー夕值) は経済的な核融合炉を指向する上で重要なパラ メータである．2.1章で述べたように遮断密度が存在する ため通常の $\mathrm{EC}$ 波では遮断密度以上の密度の加熱ができな い. この点で最近注目を集めている球状トーラス, 逆転磁 場ピンチ等では, 入射電磁波をプラズマ中で伝搬密度限界 のない静電波の電子バーンシュタイン波（EBW）を利用し て遮断密度以上のプラズマ加熱挹よび電流駆動行う検討お よび実験が進められている [58].この電子バーンシュタイ ン波は直接プラズマの外側から励起することができないた め, 電磁波からプラズマ中でモード変換を起させる必要が ある. 弱磁場から電磁波を入射しモード変換を行う方法に は 2 つあり，1つはX モードをプラズマ周辺にある $\mathrm{R}$ 遮断 層を減衰しながらも通過させすぐ近傍のアッパーハイブ リッド共鳴の近くで EBW に変換する X-B 手法であり, も

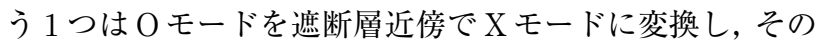




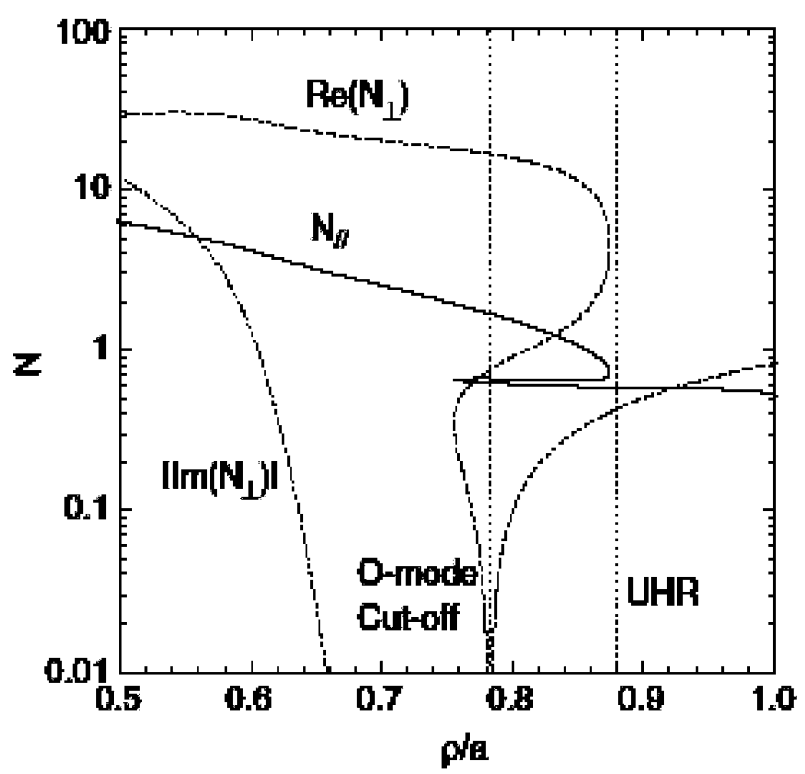

Fig. 6 Refractive indices as a function of normalized plasma radius in the LHD configuration. The wave frequency is $84 \mathrm{GHz}$. The plasma parameters are $n_{\mathrm{e} 0}=1.4 \times 10^{20} \mathrm{~m}^{-3}, T_{\mathrm{e} 0}=500 \mathrm{eV}$, and the magnetic field is $B_{0}=2.6 \mathrm{~T}$. The wave is injected from the outside of the torus. At the optimum launch, the O-mode injected from the plasma edge penetrates beyond the $\mathrm{O}$ mode cut-off layer, and then it is converted into the $X$-mode. The $\mathrm{X}$-mode is converted into the $\mathrm{B}$-mode when approaching the UHR layer.

$\mathrm{X}$ モードがアッパーハイブリッド共鳴の近くで $\mathrm{EBW} に$ に変 換する O-X-B 手法がある．Fig. 6 に LHD における O-X-B 手法の場合の屈折率と吸収率の計算例を示す [59]。この例

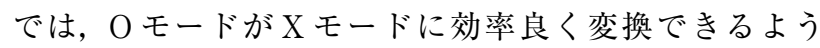
に，入射時の波数を最適化している，O-X-B 手法は，遮断 層とアッパーハイブリッド共鳴層の位置が十分離れている 場合に有効でありW7-AS で検証された [60]. 現在, NSTX やMAST等で本格的な加熱実験が計画中であり，今後の進 展が期待される.

\section{5 おわりに}

10年位前の高周波の国際会議では，EC 実験の課題とな るといつも強力なパワー源がないということであったが, この数年で主要な核融合装置で EC 装置がないものが珍し くなってきた今日この頃である。本稿ではぺージの制限で 割愛したが, 各装置においてプラズマ着火, 鋸歯状振動, H モード生成等も精力的に研究が行われている. EC 実験も 局所的な ECCDの検証等の EC 固有の実験から, ECの持つ 特性を生かした NTM 制御等，プラズマ性能を上げる研究 に進展してきている．核融合炉はアルファ粒子による電子 加熱が主体であることから，今後も EC 実験の果たす役割 は大きく, ITER での燃焼プラズマ制御に向けた研究が加 速されることを期して本稿を終えることとしたい.

\section{参考文献}

[1] K. Kobayashi et al., Fusion Eng. Des. 53, 475 (2001).

[ 2 ] R. Prater, Phys. Plasmas 11, 2349 (2004).

[ 3 ] T.C. Luce, IEEE Tran. Plasma Sci. 30, 734 (2002).
[ 4 ] B. Lloyd, Plasma Phys. Control. Fusion 40, A119 (1998).

[ 5 ] V. Erckmann and U. Gasparino, Plasma Phys. Control. Fusion 36, 1869 (1994).

[6 ] K. Sakamoto et al., Phys. Rev. Lett. 73, 3532 (1994); K. Sakamoto et al., Rev. Sci. Inst. 70, 208 (1999).

[ 7 ] S. Kubo, Kakuyugo Kenkyu 66, 581 (1991).

[ 8 ] C.P. Moeller, Proc. of 23rd Int. Conf. On Infrared and MM waves, (1998) Tul.1, p116.

[ 9 ] K. Ohkubo et al., Int. J. Infrared Millim. Waves 22, 1709 (2001).

[10] K. Takahashi et al., Fusion Eng. Des. 65, 589 (2003).

[11] H. Idei et al., Proc. of 13th Joint Workshop on ECE and ECRH, Nizhny Novgord, Russia, May 17-20, 2004.

[12] Y. Ikeda et al., Fusion Sci. Technol. 42, 435 (2002).

[13] I.A. Gorelov et al., Proc. of 13th Joint Workshop on ECE and ECRH, Nizhny Novgord, Russia, May 17-20, 2004.

[14] N.J. Lopes et al., Plasma Phys. Control. Fusion 39, 560 (1997).

[15] T.P. Goodman et al., Nucl. Fusion 43, 1619 (2003)

[16] G. Arnoux et al., Proc. of 13th Joint Workshop on ECE and ECRH, Nizhny Novgord, Russia, May 17-20, 2004.

[17] G. Giruzzi et al., Proc. of 13th Joint Workshop on ECE and ECRH, Nizhny Novgord, Russia, May 17-20, 2004.

[18] F. Leuterer et al., Nucl. Fusion 43, 1329 (2003).

[19] B. Angelini et al., Nucl. Fusion 43, 1632 (2003).

[20] S.V. Neudatchin et al., Nucl. Fusion 43, 1405 (2003).

[21] M.V. Maslov et al., Proc. of 13th Joint Workshop on ECE and ECRH, Nizhny Novgord, Russia, May 17-20, 2004

[22] E. Westerhof et al., Nucl. Fusion 43, 1371 (2003).

[23] V. Erckmann et al., Nucl. Fusion 43, 1313 (2003).

[24] V. Erckmann et al., IEEE Tran. Plasma Sci. 27, 538 (1999).

[25] S. Kubo et al., Proc. of 13th Joint Workshop on ECE and ECRH, Nizhny Novgord, Russia, May 17-20, 2004.

[26] H. Zushi et al., Nucl. Fusion 431600 (2003).

[27] S. Tanaka et al., Proc. 11th Int. Conf. Plasma Phys. and Control. Nucl. Fusion Resarch. Kyoto, Japan, 1986, Paper No. IAEA-F-II-6.

[28] S. Coda et al., Plasma Phy. Control. Fusion 42, B311 (2000).

[29] C.B. Forest et al., Phys. Rev. Lett. 73, 2444 (1994).

[30] T.C. Luce et al., Phys. Rev. Lett. 83, 4550 (1999).

[31] T. Suzuki et al., Nucl. Fusion 44, 699 (2004).

[32] E. Westerhof et al., Fusion Eng. Des. 53, 259 (2001).

[33] V.V. Alikaev et al., Nucl. Fusion 32, 1811 (1992).

[34] O. Sauter et al., Phys. Plasmas 4, 1654 (1997).

[35] H. Zohm et al., Nucl. Fusion 39, 577 (1999).

[36] A. Isayama et al., Plasma Phys. Control. Fusion 42, L37 (2000).

[37] G. Gantenbein et al., Phys. Rev. Lett. 85, 1242 (2000).

[38] R.J. La Haye et al., Phys. Plasmas 9, 2051 (2002).

[39] A. Isayama et al., Nucl. Fusion 43, 1272 (2003).

[40] K. Nagasaki et al., Nucl. Fusion 43, L7 (2003).

[41] H. Idei et al., Phys. Rev. Lett. 712220 (1993).

[42] H. Maassberg, C.D. Beidler, U. Gasparino et al., Phys. Plasmas 7575 (2000).

[43] T. Shimozuma et al., Plasma Phys. Control. Fusion 45, 1183 (2003).

[44] A. Fujisawa et al., Proc. 20th Fusion Energy Conf, EX/8-5 $\mathrm{Rb}$ (2004).

[45] N.J. Lopes Cardozo et al., Plasma Phys. Control. Fusion 
39, B303 (1997).

[46] K.A. Razumova et al., Plasma Phys. Rep. 27, 273 (2001).

[47] Y. Ikeda et al., Proc. of 12th Joint Workshop on ECE and ECRH, Aix-en-Provence, France, May 17-20, (2002) p.247.

[48] S. Ishida et al., Proc 16th Int. Conf. on Fusion Energy, Montreal, Canada, (1996) Vol. 1, p.315.

[49] Y. Koide et al., Phys. Rev. Lett. 72, 3662 (1994).

[50] F. Leuterer et al., Fusion Eng. Des. 53, 277 (2001).

[51] K.H. Burrell et al., Nucl. Fusion 44, 1555 (2004).

[52] S. Ide et al., Nucl. Fusion 44, 87 (2004).
[53] H. Takenaga et al., Nucl. Fusion 43, 1235 (2003).

[54] M. Cox et al., Nucl. Fusion 33, 1657 (1993).

[55] N. J. Lopes Cardozo, Plasma Phys. Control. Fusion 37, 799 (1995).

[56] F. Ryter, Plasma Phys. Control. Fusion 43, A323 (2001).

[57] K. Toi, J. Plasma Fusion Res. 78, 895 (2002).

[58] T. Maekawa, J. Plasma Fusion Res. 78, 508 (2002).

[59] K. Nagasaki et al., Plasma Phys. Control Fusion 44, 409 (2002).

[60] H.P. Laqua et al., Phys. Rev. Lett. 78, 3647 (1997). 